\title{
Effects of vegetation patterns and environmental factors on woody regeneration in semi-arid oak-dominated forests of western Iran
}

\author{
Mirzaei JAVAD ${ }^{1}$, Heydari MEHDI ${ }^{1 *}$, Bernard PREVOSTO ${ }^{2}$ \\ ${ }^{1}$ Department of Forest Science, Faculty of Agriculture, University of Ilam, Ilam 69315-516, Iran; \\ ${ }^{2}$ Irstea, UR Ecosystèmes Méditerranéens et Risques, 3275 route de Cézanne, CS 40061, F-13612 Aix-en Provence Cedex 5, \\ France
}

\begin{abstract}
This study assesses the effects of vegetation patterns and environmental factors on the abundance of natural tree and shrub regeneration in semi-arid forests of the Zagros Mountains, western Iran. We sampled 120 releves at different topographic positions in a protected area of the studied region. Floristic composition, slope, elevation and soil properties were recorded at each releve, and woody seedling density was measured. We have first discerned five floristic groups using two-way indicator species analysis (TWINSPAN), detrended correspondence analysis (DCA), and canonical correspondence analysis (CCA) and then explored the relationships among the floristic group compositions, environmental factors and seedling densities. The indicator species of the five groups were Quercus brantii, Acer monspessulanum, Cerasus microcarpa, Rhamnus arvensis and Astragalus licyoides. Our results indicated that these groups were significantly affected by elevation and soil properties and the soil properties refer to: EC (electrical conductivity), N (nitrogen), K (potassium), OM (organic matter), and bulk density. Woody regeneration was composed of Q. brantii, A. monspessulanum, C. microcarpa, Amygdalus scoparia and Crataegus pontica seedlings. The highest density of seedlings was found for Q. brantii (97.14 $( \pm 48.00)$ plants $\left./ \mathrm{hm}^{2}\right)$ and the lowest for A. scoparia $\left(2.28( \pm 1.50)\right.$ plants $\left./ \mathrm{hm}^{2}\right)$. Quercus brantii was the dominant species and the seedling density was positively correlated with soil $\mathrm{pH}$ and $\mathrm{P}$ (phosphorus) values. Amygdalus scoparia regeneration was negatively correlated with elevation, and the seedling density peaked in $C$. microcarpa group. There was no significant variation in distribution of $C$. pontica seedlings among the groups, but the seedling density of this species was positively correlated with slope and K. Cerasus microcarpa seedlings were more abundant in the Q. brantii group than in other groups. This study showed that the regeneration of tree and shrub species was unequally distributed in different floristic groups for some species (A. scoparia and C. microcarpa) but not for other (Q. brantii and C. pontica) and was generally correlated with some environmental factors, particularly elevation, slope and soil nutrients ( $\mathrm{P}$ and $\mathrm{K})$. These results are a first step to implement future management and restoration strategies for promoting forest regeneration.
\end{abstract}

Keywords: abiotic factors; community classification; Zagros Mountains; natural regeneration

Citation: Mirzaei JAVAD, Heydari MEHDI, Bernard PREVOSTO. 2017. Effects of vegetation patterns and environmental factors on woody regeneration in semi-arid oak-dominated forests, western Iran. Journal of Arid Land, 9(3): 368-378. doi: $10.1007 / \mathrm{s} 40333-017-0013-7$

\section{Introduction}

The Zagros Mountains in western Iran form its largest mountain range in Iran. This area contains various ecosystems, prominent among which are forests in a semi-arid climate. These seasonal dry forests provide a home and livelihood for about $10 \%$ of the country's population (Salehi et al., 2010). But, they undergo increasingly strong anthropogenic pressure, causing severe degradation

*Corresponding author: Heydari MEHDI (E-mail: M_heydari23@yahoo.com)

Received 2016-06-04; revised 2016-11-01; accepted 2017-04-07

(C) Xinjiang Institute of Ecology and Geography, Chinese Academy of Sciences, Science Press and Springer-Verlag Berlin Heidelberg 2017

http://jal.xjegi.com; www.springer.com/40333 
of these ecosystems. More than $1.7 \times 10^{6} \mathrm{hm}^{2}$ of the forests in the Zagros Mountains (namely Zagros forests) have been deforested since 1962. Studies suggest that increasing population, low level of development, and high dependency of local communities on the forests for their primary livelihoods are the main reasons for the deforestation (Ghazanfari et al., 2004; Heydari et al., 2016).

The natural regeneration of these forests is very slow, thus jeopardizing the ecological services of these ecosystems. Different reasons are offered to explain this poor regeneration, and many studies have emphasized the role of overgrazing pressure limiting woody species establishment in the Zagros Mountains (Jazirehi and Ebrahimi, 2003; Pourhashemi et al., 2004; Sagheb-Talebi et al., 2004). Unexpectedly, the lack of natural regeneration is also observed even in the Zagros forests that enjoy protected status, where grazing pressure and other anthropogenic disturbances are minimal (Pourhashemi et al., 2004).

This observation points to the involvement of other factors. The influence of the main physiographic variables on the regeneration process has been largely documented, and numerous studies have emphasized the role of elevation, slope and topography as key factors influencing above- and below-ground conditions, and thereby regeneration success (e.g., Peterson and Pickett, 1990; van Mantgem et al., 2006; Martín-Alcón and Coll, 2016). The relationships linking regeneration and soil physical and chemical properties have also been explored (e.g., Kabrick et al., 2005; Hattori et al., 2013), although our understanding of them is still limited (Dickie et al., 2007). In Mediterranean regions, previous studies have shown that soil properties such as texture (Ibáñez et al., 2014), phosphorus availability (Sardans et al., 2005; Pascual et al., 2012), potassium availability (Gómez-Aparicio et al., 2005; Sardans et al., 2005) and nitrogen availability (Sardans et al., 2006) often strongly influence tree regeneration. However, the natural regeneration of woody species in different ecological species groups has been under-researched.

Ecological species groups refer to the plants that share similar affinities to environmental conditions and tend to occupy the same ecological niches across the landscape (Adel et al., 2014). By integrating soil and physiographic information, ecological species grouping offers an effective way to devise a land classification that can then be used to support vegetation mapping and management strategies (Host and Pregitzer, 1991). There is accordingly a need to know more about the relationships between ecological plant species groups and patterns of regeneration (composition, density) of the main woody species in semi-arid regions.

This study was designed to fill this gap. We hypothesized that the natural regeneration of shrub and tree species varies with floristic compositions of the communities and environmental factors (including soil physical and chemical properties). To test this hypothesis, we adopted the following approach: (i) we first produced a floristic classification of the main communities occurring in our study area, and explored the correlations between those communities and environmental factors, and (ii) we then studied woody seedling density and composition in the different communities and examined the links between regeneration and environmental factors.

\section{Materials and methods}

\subsection{Study area}

The study area was a natural forest on Manesht-Ghalarang, a protected area of the Zagros forests in Ilam Province of western Iran $\left(36^{\circ} 00^{\prime}-36^{\circ} 45^{\prime} \mathrm{N}, 60^{\circ} 05^{\prime}-60^{\circ} 50^{\prime} \mathrm{E}\right.$; Fig. 1). The elevation ranges from 1400 to $2200 \mathrm{~m}$ a.s.l. and slope from $5^{\circ}$ to $75^{\circ}$. Slope aspects were mainly north- and south-facing. The dominant species was the Persian oak (Quercus brantii), which made up nearly $90 \%$ of the overstorey and was accompanied with a few other tree species such as Pistacia atlantica, Crataegus pontica, and Acer monspessulanum. The understorey comprised diverse plant species. In total, 52 families, 156 genera and 231 plant species have been found in this area. The largest family is Asteraceae with 18 genera and 29 species, and the largest genus is Astragalus with 11 species (Darvishnia et al., 2012). Soils were calcic/calcareous, the overall texture was sandy clay, and the dominant parent rock was limestone. The climate was semi-arid: mean annual rainfall, maximum temperature and minimum temperature were $320 \mathrm{~mm}, 28^{\circ} \mathrm{C}$ and $5.8^{\circ} \mathrm{C}$, respectively (Mirzaei, 2016). 


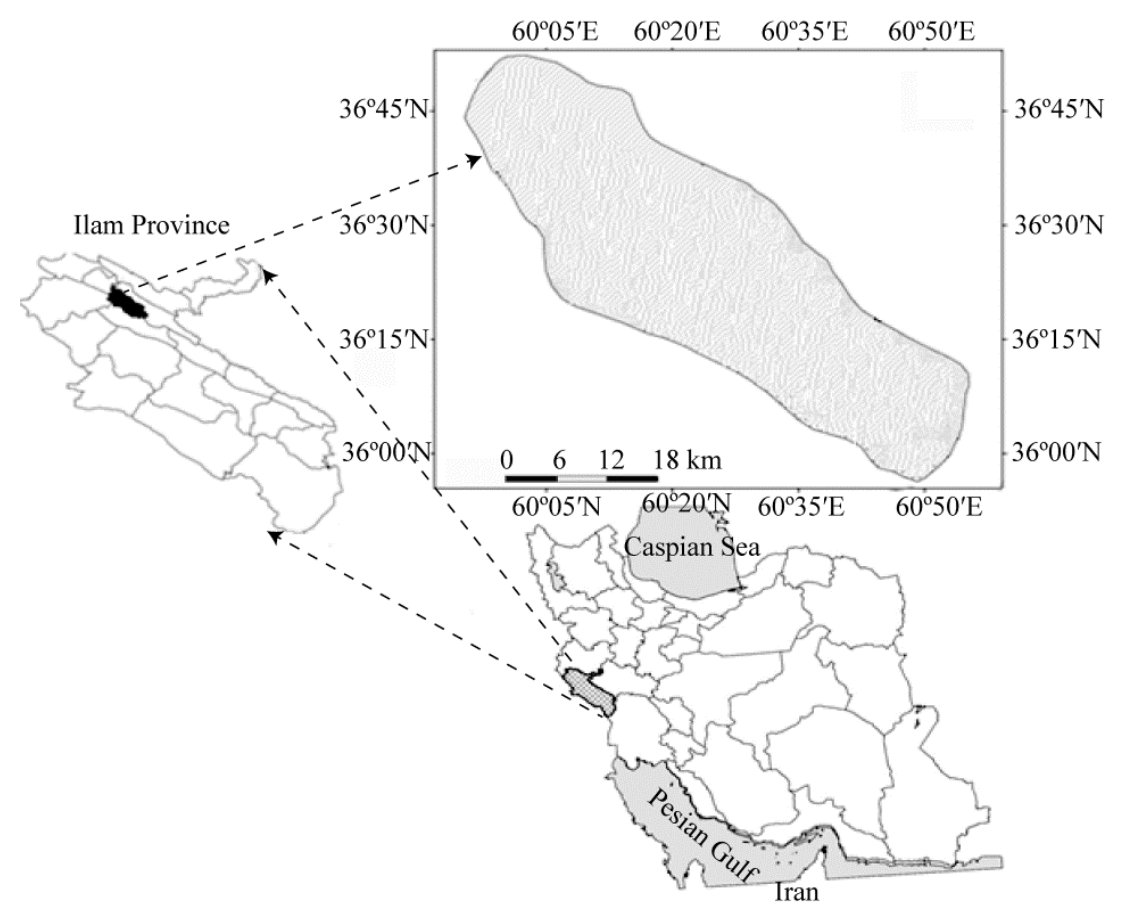

Fig. 1 Location of the study area

\subsection{Sampling method and data collection}

In the study area, we set up 19 transects with lengths ranging from 700 to $1400 \mathrm{~m}$ from lower to upper hillside. Totally, we sampled 120 plots $(20 \mathrm{~m} \times 20 \mathrm{~m}$ each $)$. The location of transects and releves were selected so as to represent a wide range of physiographic and environmental variations. In each sampling plot, elevation, aspect and slope were recorded in the field using GPS. A floristic releve was then taken on each plot: each vascular species was identified and named according to the available literature (Mozaffarian, 2008). Abundance-dominance for each species was estimated on the Braun-Blanquet scale (Müller-Dombois and Ellenberg, 1974).

To study the physical and chemical properties of soils, three composite soil samples were collected at depth $0-20 \mathrm{~cm}$ near the centre of each plot (120 samples). These soil samples were placed in plastic bags and sent immediately to the laboratory for soil analysis.

Soil samples were air-dried and sieved to $2 \mathrm{~mm}$ meshes, and analyzed for soil texture, electrical conductivity $(\mathrm{EC}), \mathrm{pH}$, bulk density, nitrogen $(\mathrm{N})$, phosphorus $(\mathrm{P})$, potassium $(\mathrm{K})$, carbon $(\mathrm{C})$ and organic matter $(\mathrm{OM})$. The soil texture was measured hydrometrically, the bulk densities gravimetrically. The soil EC and $\mathrm{pH}$ were measured in deionized water (McLean, 1982). Total N was determined by the Kjeldahl method (Bremner, 1996). Available P was determined according to the method of Watanabe and Olsen (Watanabe and Olsen, 1965). Exchangeable K was analyzed using inductively coupled plasma atomic emission spectroscopy (Kalra and Maynard, 1991). Total OM was determined using a wet oxidation technique (Walkley and Black, 1934). The abundance and composition of natural tree and shrub regeneration were recorded by establishing a $10 \mathrm{~m} \times 10 \mathrm{~m}$ central subplot on each sampling plot. On each subplot, the number of seedlings and samplings of tree and shrub species that were $\geq 5 \mathrm{~cm}$ tall and $<1 \mathrm{~cm}$ diameter at breast height were recorded (hereafter referred to as 'seedlings').

\subsection{Data analysis}

To draw up a floristic typology of our area as a framework for further analysis, a classification was undertaken using two-way indicator species analysis (TWINSPAN, Hill, 1979) on a quantitative data matrix comprising 120 releves and 211 species after discarding species with three or fewer occurrences. Each plant of the releve was given a coefficient of 
abundance-dominance (from 1 to 5 ) that reflects the cover of the plant, i.e., $1:<5 \%, 2: 5 \%-25 \%$, 3: $25 \%-50 \%, 4: 50 \%-75 \%, 5:>75 \%$. Classification was truncated at the fourth division after examination of the resulting groups and complementary ordination by the detrended correspondence analysis (DCA; Hill and Gauch Jr, 1980). This analysis resulted in five vegetation groups (i.e., plant communities), which were named after their dominant species. In order to detect correlations of these vegetation groups with environmental factors (slope, elevation and soil properties), canonical correspondence analysis (CCA) was undertaken using a second matrix formed by 120 releves and the 13 environmental factors considered. Relationships between the ordination axes and community and environmental variables were tested using Pearson's simple linear correlation coefficient. The means and standard errors of the seedling densities (plants $/ \mathrm{hm}^{2}$ ), and environmental variables were calculated for the five groups, and statistical differences were tested using ANOVA and Duncan's multiple comparison tests.

Pearson's correlation was used to determine the correlation coefficients between soil and physiographic factors and seedling densities. Statistical analyses were carried out in SPSS (version 16.0) and PC-ORD program (version 4.17).

\section{Results}

\subsection{Ecological species groups}

From the results of vegetation classification using TWINSPAN, the 120 plots were classified into five groups (Fig. 2). The indicator species of the clustering dendrogram for the successive divisions are as follows: first division: Tulipa stylosa on the left and Aegilops triuncialis on the right; second division: Colchicum robustum (left), and Quercus brantii and Daphne macronata (right); third division: Cerasus microcarpa (left) and Acer monspessulanum (right); fourth division: Astragalus licyoides (left) and Amygdalus scoparia and Ranunculus arvensis (right).

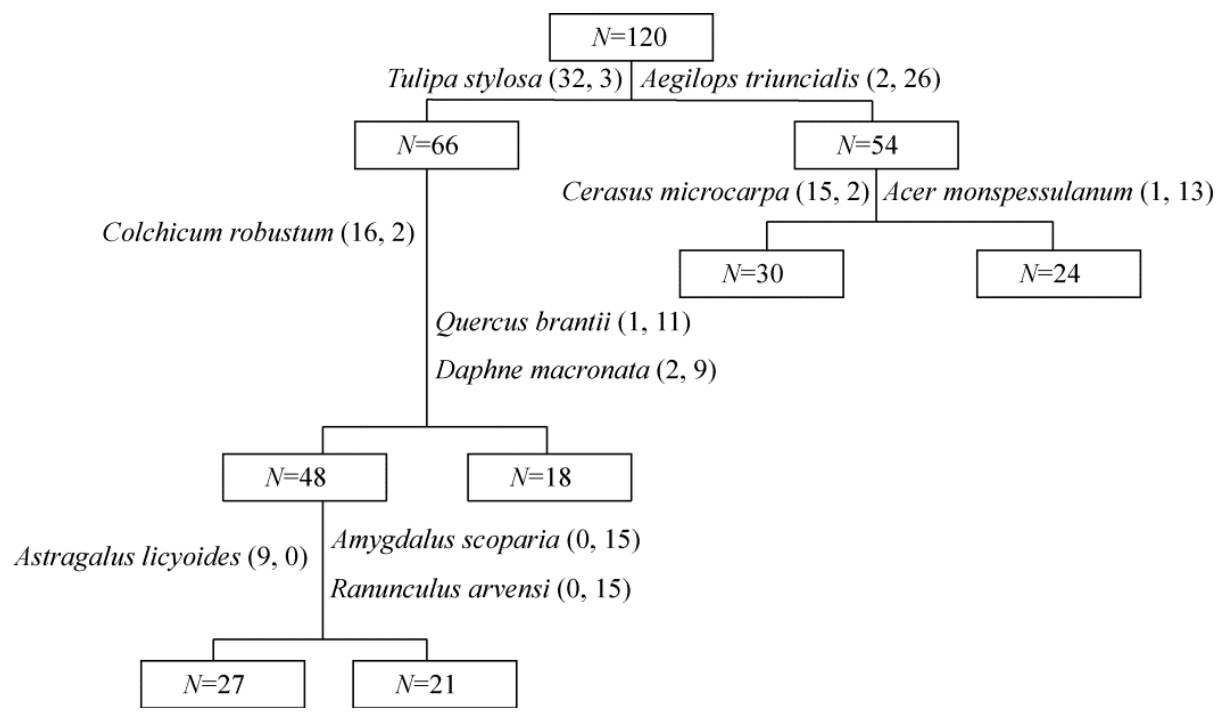

Fig. 2 Dendrogram of two-way indicator species analysis for vegetation in the study area

According to the eigenvalue of each division, the vegetation in the study area was classified into five ecological species groups named after their dominant species: Group 1: C. microcapa; Group 2: Q. brantii; Group 3: A. monspessulanum; Group 4: A. scoparia; Group 5: A. licyoides.

The detrended correspondence analysis (DCA) was used to search for major gradients in species compositions and to describe the general pattern of species distribution along the environmental gradients. It was found that the first and second axes explained respectively $63.0 \%$ and $35.3 \%$ of the total variation (Fig. 3). The first axis separated the first, third and fourth groups, while the second axis separated the second and fifth groups. The application of DCA thus confirmed the separation between these communities that was indicated by the TWINSPAN analysis. 


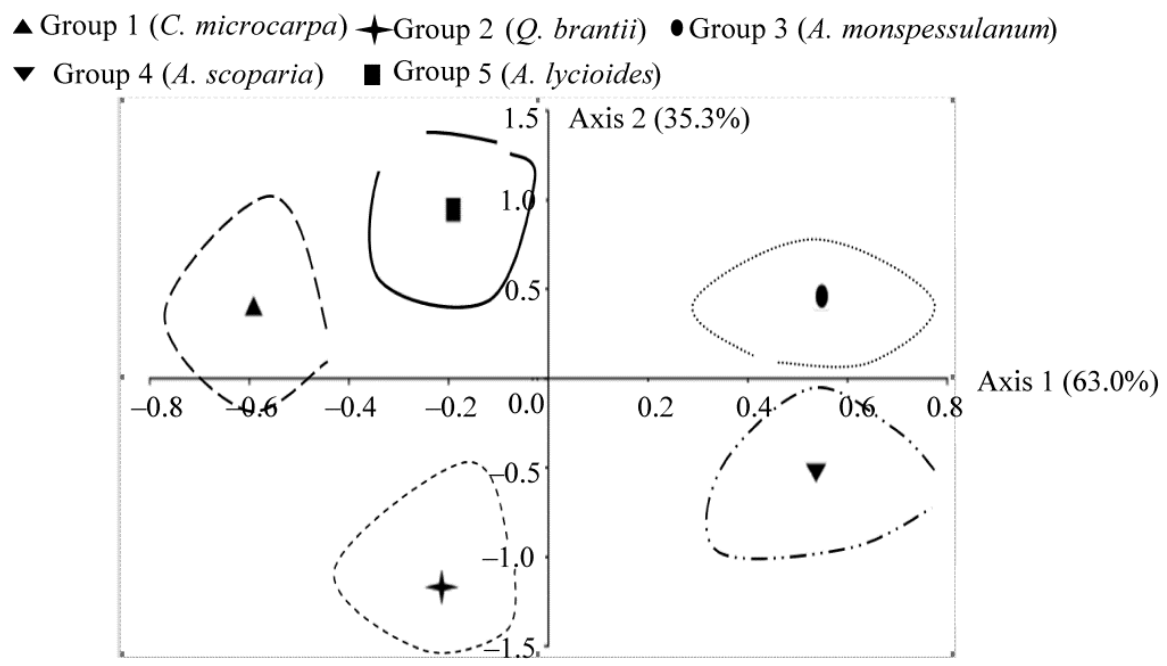

Fig. 3 Detrended correspondence analysis ordination diagram based on plant species. The numbers in parentheses indicate the percentage of total variance explained by each axis.

Canonical correspondence analysis (CCA) was used to analyze the relationship between species composition and the environmental variables (Fig. 4). The percentage variances of the species-environment relation for axes of CCA (and their eigenvalues) were $50.3 \%$ and $32.3 \%$ for axes 1 and 2, respectively. The species-environment correlation coefficients calculated for the first two axes of CCA were 0.91 and 0.79 . The highest coefficients with the first CCA axis were found for soil organic carbon $(0.68 ; P<0.01), \mathrm{K}(0.41 ; P<0.05)$, elevation $(-0.78 ; P<0.01), \mathrm{N}$ $(0.51 ; P<0.05)$ and clay $(-0.46 ; P<0.05)$. The second CCA axis was closely correlated with bulk density $(0.89 ; P<0.01)$.

The CCA results showed that soil nitrogen and organic carbon were the most important factors in the first group. Potassium was the separation (deciding) factor in the second group. The third and fourth groups were formed around the left side of the first axis. Clay and elevation were higher in the third and fourth groups. Soil bulk density was the separation (deciding) factor in the fifth group (Fig. 4).

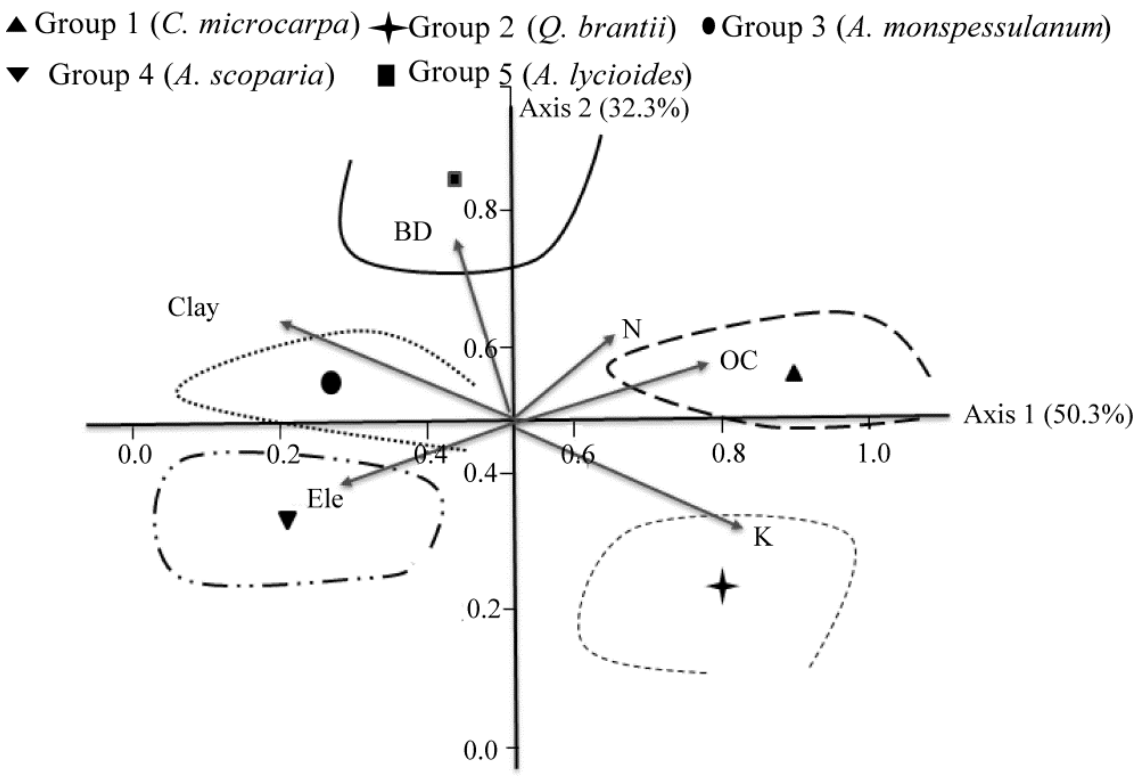

Fig. 4 Ordination diagram of the first two axes of canonical correspondence analysis (CCA) and the location center of the five identified ecological species groups. Ele, elevation; BD, bulk density; OC, organic carbon; N, nitrogen; K, potassium. 


\subsection{Environmental variations between ecological species groups}

Table 1 shows significant differences between the different groups in elevation $(P<0.001)$ and some soil parameters: bulk density $(P=0.002), \mathrm{EC}(P<0.001), \mathrm{N}(P=0.021), \mathrm{OM}(P<0.001)$ and $\mathrm{K}$ $(P<0.001)$. Group 4 (A. scoparia) was at the highest and Group $2(Q$. brantii) at the lowest elevation above sea level. Soil bulk density was highest for Group 5 and lowest for Group 1 (Table 1). Group 1 showed the highest OM, $\mathrm{C}$ and $\mathrm{N}$ values. The $\mathrm{K}$ content was higher in Group 2 (Q. brantii) than in the other groups (Table 2).

Table 1 Elevation, slope, clay, sand, silt, bulk density and $\mathrm{pH}$ values for the different groups

\begin{tabular}{cccccccc}
\hline Group & Elevation (m) & Slope (\%) & Clay (\%) & Sand (\%) & Silt (\%) & $\begin{array}{c}\text { Bulk density } \\
\left(\mathrm{g} / \mathrm{cm}^{3}\right)\end{array}$ & $\mathrm{pH}$ \\
\hline C. microcarpa & $1616 \pm 107^{\mathrm{ab}}$ & $37.5 \pm 6.4$ & $26.2 \pm 1.6$ & $37 \pm 2.4$ & $36.8 \pm 1.9$ & $1.24 \pm 0.03^{\mathrm{c}}$ & $7.19 \pm 0.02$ \\
Q. brantii & $1178 \pm 118^{\mathrm{c}}$ & $31.0 \pm 4.8$ & $27.8 \pm 3.3$ & $38.4 \pm 1.6$ & $33.8 \pm 1.5$ & $1.43 \pm 0.05^{\mathrm{ab}}$ & $7.17 \pm 0.03$ \\
A. monspessula & $1657 \pm 54^{\mathrm{ab}}$ & $29.1 \pm 4.1$ & $30.0 \pm 1.3$ & $38.0 \pm 3.1$ & $32.0 \pm 3.1$ & $1.28 \pm 0.08^{\mathrm{bc}}$ & $7.16 \pm 0.05$ \\
A. scoparia & $1845 \pm 43^{\mathrm{a}}$ & $41.0 \pm 5.3$ & $25.4 \pm 2.3$ & $41.2 \pm 2.5$ & $33.4 \pm 3.0$ & $1.43 \pm 0.06^{\mathrm{ab}}$ & $7.17 \pm 0.03$ \\
A. licyoides & $1560 \pm 67^{\mathrm{b}}$ & $41.6 \pm 5.8$ & $23.8 \pm 2.2$ & $42.1 \pm 1.8$ & $34.1 \pm 1.9$ & $1.55 \pm 0.05^{\mathrm{a}}$ & $7.26 \pm 0.04$ \\
\hline
\end{tabular}

Note: Different lowercase letters in the same column indicate significant differences $(P<0.05)$. No letter indicates no significant differences. Mean \pm SE.

Table 2 Soil EC and chemical properties for the different groups

\begin{tabular}{|c|c|c|c|c|c|c|}
\hline Group & $\mathrm{EC}(\mathrm{dS} / \mathrm{m})$ & $\mathrm{C}(\%)$ & OM (\%) & N (\%) & $\mathrm{P}(\%)$ & $\mathrm{K}(\%)$ \\
\hline C. microcarpa & $0.65 \pm 0.02^{b}$ & $2.75 \pm 0.4^{\mathrm{a}}$ & $4.73 \pm 0.8^{\mathrm{a}}$ & $0.43 \pm 0.05^{\mathrm{a}}$ & $0.040 \pm 0.003^{\mathrm{b}}$ & $0.013 \pm 0.0010^{\mathrm{ab}}$ \\
\hline Q. brantii & $0.65 \pm 0.02^{\mathrm{b}}$ & $2.68 \pm 0.54^{\mathrm{a}}$ & $4.6 \pm 0.4^{\mathrm{a}}$ & $0.36 \pm 0.02^{\mathrm{a}}$ & $0.055 \pm 0.003^{\mathrm{a}}$ & $0.017 \pm 0.0010^{\mathrm{a}}$ \\
\hline A. monspessulanum & $0.79 \pm 0.04^{\mathrm{a}}$ & $2.43 \pm 0.37^{b}$ & $4.17 \pm 0.5^{\mathrm{b}}$ & $0.23 \pm 0.07^{\mathrm{b}}$ & $0.037 \pm 0.002^{\mathrm{c}}$ & $0.011 \pm 00070^{b c}$ \\
\hline A. scoparia & $0.59 \pm 0.04^{\mathrm{b}}$ & $1.97 \pm 0.25^{\mathrm{c}}$ & $3.4 \pm 0.4^{\mathrm{c}}$ & $0.26 \pm 0.04^{\mathrm{b}}$ & $0.038 \pm 0.001^{\mathrm{c}}$ & $0.009 \pm 0.0006^{\mathrm{c}}$ \\
\hline A. licyoides & $0.65 \pm 0.01^{\mathrm{b}}$ & $1.8 \pm 0.37^{\mathrm{c}}$ & $3.0 \pm 0.4^{\mathrm{c}}$ & $0.22 \pm 0.02^{\mathrm{b}}$ & $0.038 \pm 0.001^{\mathrm{c}}$ & $0.013 \pm 0.0007^{\mathrm{ab}}$ \\
\hline
\end{tabular}

Note: Different lowercase letters in the same column indicate significant differences $(P<0.05)$. EC, electrical conductivity; $\mathrm{C}$, carbon; $\mathrm{OM}$, organic matter; $\mathrm{N}$, nitrogen; $\mathrm{P}$, phosphorus; $\mathrm{K}$, potassium. Mean $\pm \mathrm{SE}$.

\subsection{Seedling densities}

Five tree and shrub species regenerated naturally in the Manesht-Ghalarang region including $Q$. brantii, A. monspessulanum, A. scoparia, C. pontica and C. microcarpa. The results show that $Q$. brantii (mean=97.14 plants $/ \mathrm{hm}^{2}$ ) and A. scoparia (mean=2.28 plants $/ \mathrm{hm}^{2}$ ) had respectively the highest and lowest seedling densities (Table 3).

Table 3 Mean and standard deviation of seedling density values for the different groups

\begin{tabular}{cccc}
\hline Group & Life form & Mean $\left(\right.$ plants $\left./ \mathrm{hm}^{2}\right)$ & Standard deviation \\
\hline C. microcarpa & Tree & 26.80 & 17.90 \\
Q. brantii & Tree & 97.14 & 48.78 \\
A. scoparia & Shrub & 2.28 & 1.50 \\
A. monspessulanum & Tree & 40.91 & 10.73 \\
C. pontica & Shrub & 2.96 & 1.70 \\
\hline
\end{tabular}

Density of $Q$. brantii seedlings did not vary significantly among the ecological species groups (Fig. 5a). By contrast, regeneration of $A$. monspessulanum, the second most abundant regenerating species in the study site (mean $=40.91$ plants $/ \mathrm{hm}^{2}$ ) peaked in A. monspessulanum species group (Fig. 5b). A. scoparia, the least abundant regenerating species (mean=2.28 plants $/ \mathrm{hm}^{2}$ ), was most abundant in the C. microcarpa group (Fig. 5c), whereas no preferential regeneration of $C$. pontica was found among the five groups (Fig. 5d). Last, the regeneration of $C$. microcarpa was highest in the Q. brantii group (Fig. 5e).

\subsection{Relationship between regeneration and environmental factors}

Pearson's correlation analysis showed significant correlations between natural regeneration and 


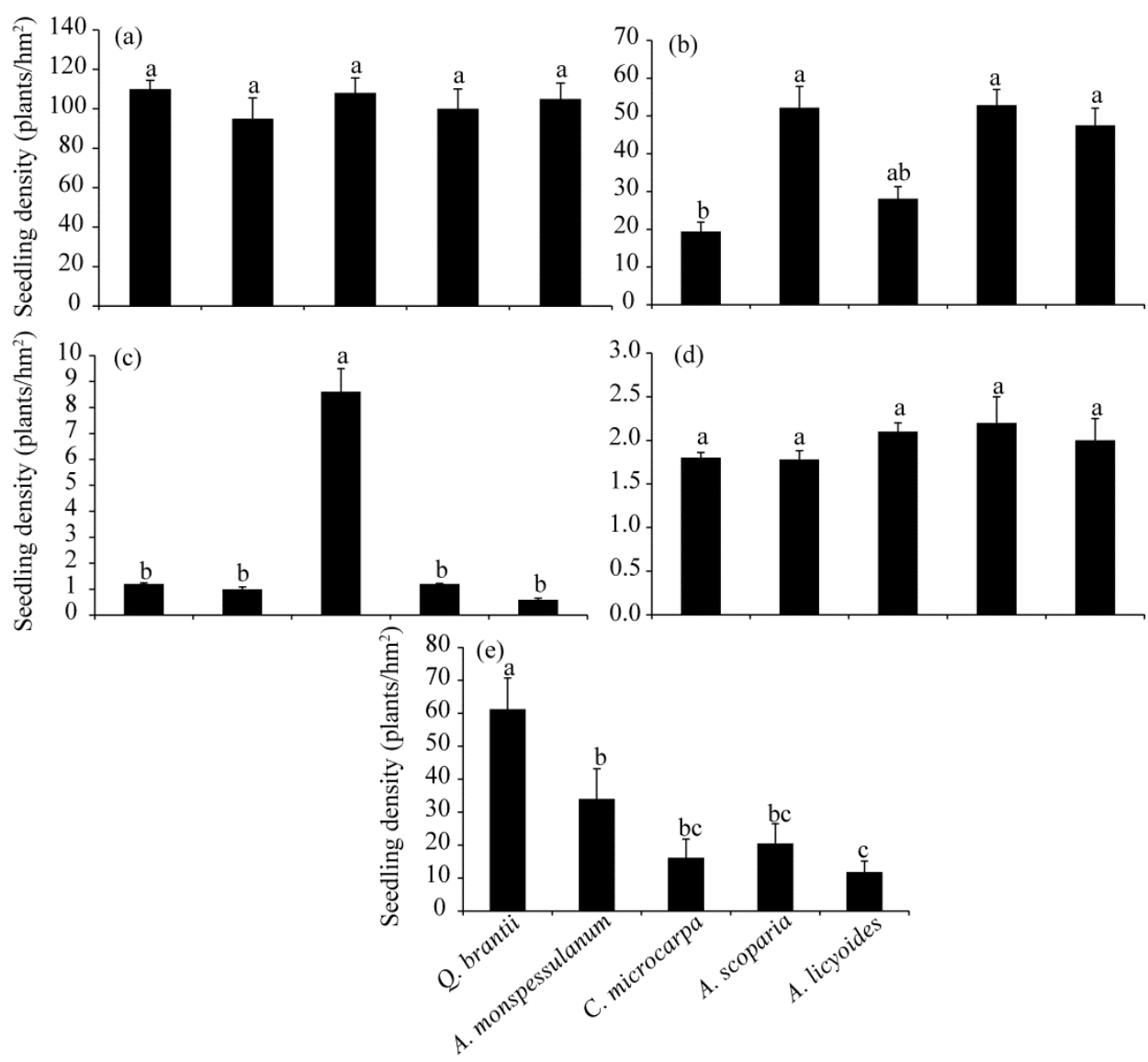

Fig. 5 Seedling densities of Q. brantii (a), A. monspessulanum (b), A. scoparia (c), C. pontica (d) and C. microcarpa (e) among the five groups. Different letters indicate significant differences $(P<0.05)$. Bars indicate standard errors.

some environmental factors (Table 4). Specifically, Q. brantii regeneration was found preferentially on soils with higher $\mathrm{pH}$ and higher P content. Acer monspessulanum seedlings were more numerous at higher elevations on steeper slopes, and on sandy soils with higher $\mathrm{K}$ content. By contrast, A. scoparia regeneration was less abundant at high elevation, whereas regeneration of C. microcarpa seedlings was positively correlated with soil sand content and negatively with soil bulk density. Last, seedling density of $C$. pontica increased with the increases in slope and soil K content (Table 4).

\section{Discussion}

The results of this study show that natural regeneration in the study area was quite low even though this area was protected. Anthropogenic disturbances, such as livestock grazing, overexploitation of the firewood resource, agriculture in the forest understorey or fires, were largely minimized in the study area. We found that $Q$. brantii seedlings were the most abundant among the different shrub and tree species in the Persian oak forests. Quercus brantii seedlings distribution can be explained by soil $\mathrm{P}$ content. This finding is consistent with previous studies reporting a significant relationship between $\mathrm{P}$ content and establishment of different Mediterranean oak species (Gómez-Aparicio et al., 2005, 2008). Mirzaei et al. (2007) and Basiri (2011) also noted a more abundant Q. brantii or Q. libani regeneration with increasing K soil content. These previous results are in line with previous observations indicating that $\mathrm{P}$ and $\mathrm{K}$ (rather than $\mathrm{N}$ or $\mathrm{C}$ ) are more limiting factors in Mediterranean forests and shrublands 
Table 4 Matrix showing Pearson's correlation $(r)$ between topography and soil physical-chemical properties and natural regeneration of tree and shrub species

\begin{tabular}{lccccccc}
\hline Group & Elevation & Slope & Clay & Silt & Sand & Bulk density & pH \\
\hline Q. brantii & 0.120 & 0.191 & -0.150 & 0.032 & 0.143 & -0.057 & $0.261^{*}$ \\
A. monspessulanum & $0.312^{*}$ & $0.293^{*}$ & -0.226 & -0.130 & $0.347^{*}$ & -0.211 & 0.021 \\
A. scoparia & $-0.296^{*}$ & -0.143 & -0.170 & 0.130 & -0.145 & -0.212 & -0.190 \\
C. microcarpa & -0.067 & -0.222 & -0.009 & -0.107 & $0.329^{*}$ & $-0.309^{*}$ & 0.121 \\
C. pontica & -0.111 & $0.376^{* *}$ & 0.217 & 0.094 & -0.117 & -0.178 & -0.170 \\
\hline \hline Group & $\mathrm{EC}$ & $\mathrm{C}$ & $\mathrm{OM}$ & $\mathrm{N}$ & $\mathrm{P}$ & $\mathrm{K}$ & -0.140 \\
\hline Q. brantii & -0.175 & 0.120 & 0.172 & 0.149 & $0.324^{*}$ & 0.198 & $0.533^{* *}$ \\
A. monspessulanum & -0.033 & 0.119 & 0.110 & 0.004 & 0.198 & -0.201 \\
A. scoparia & 0.109 & 0.046 & -0.087 & 0.009 & 0.064 & 0.209 & 0.088 \\
C. microcarpa & -0.136 & -0.108 & 0.121 & -0.024 & 0.143 & $0.297^{*}$ \\
C. pontica & -0.057 & 0.068 & 0.154 & 0.105 & 0.143
\end{tabular}

Note: EC, electrical conductivity; C, carbon; OM, organic matter; N, nitrogen; P, phosphorus; K, potassium; ${ }^{*}$ and ${ }^{* *}$ indicate the correlation significant at $P<0.05$ and $P<0.01$ levels, respectively.

(Gómez-Aparicio et al., 2005; Sardans et al., 2005). These elements (P and K) were shown to have enhanced the water-use efficiency under drought conditions, thus improving the seedling survival and growth (Bradbury and Malcolm, 1977; Sardans et al., 2005). Seedling density of A. monspessulanum was greater at high elevations on steep slopes, i.e., the conditions where human disturbances are minimal and climatic conditions are milder. It means that the high-elevation and steep-slope conditions provide A. monspessulanum seedlings with shelter against herbivory and human disturbances. This result is consistent with other studies on tree species in dry regions (Mahoney and Rood, 1998; Taylor et al., 1999). Park (2001) also observed that regeneration of Pinus durangensis, $P$. teocote and $Q$. crassifolia was more abundant on steep-sloped sites with stony soils, while Mirzaei et al. (2007) noted a more abundant recruitment of woody species regeneration in habitats of the Zagros region with northern exposure. Explaining the positive influence of soil sand content on regeneration of this species (and also C. microcarpa) is not straightforward. Water-holding capacity is lower in a sandy texture than in fine textures (e.g., clayey or silty), but a higher sand content can also imply a more favourable soil porosity, allowing better exploration of the root system or easier water percolation to deeper soil layers, thus ensuring the availability of water in the dry season (Ibáñez et al., 2014).

The natural regeneration of $A$. scoparia in our study area was very low (mean=2.28 plants $\left./ \mathrm{hm}^{2}\right)$. A similar finding was also reported by Marvie-Mohadjer (2005) and Mirzaei et al. (2007) in the same region. According to these authors, the lack of recruitment is because this species produces seeds that do not easily absorb water owing to an impermeable seed case, and water absorption (and so seed germination) is particularly limited in soils with high bulk density and low litter content. We found that the abundance of A. scoparia seedlings decreased with elevation. This can be explained by the preferential distribution of the mother trees at low elevations, whereas the dissemination of this heavy-seeded species is limited at higher elevations (Marvie-Mohadjer, 2005).

In this study we found a robust positive correlation between soil sand content and $C$. microcarpa seedling density, but a negative correlation with soil bulk density. Increasing soil bulk density causes a decrease in soil porosity and soil permeability, thus reducing available soil water content. These conditions are unfavourable to species recruitment (Rab, 1996) as observed for instance for P. tabulaeformis (Zhao et al., 2006).

The seedlings of $C$. pontica were preferentially found on steep slopes. This species produces relatively thin seeds that can be readily dispersed by wind and is thus able to colonize habitats located on steep slopes. Similarly, Tsitsoni (1997) found that slope is also an important factor explaining the natural regeneration of forests of the Kassandra Peninsula (northern Greece). 
Finally, we want to point out that human-disturbance legacies in arid or semi-arid landscapes may remain over a long period (decades or even centuries) owing to the naturally low soil fertility (e.g., Swetnam et al., 1999; Ko et al., 2011). These legacies may also be somewhat related to the observed slow regeneration processes even after an arid or semi-arid landscape has been under the protection. However, no attention was paid to human-disturbance legacy issues and their possible association with slow regeneration processes.

\section{Conclusions}

The results of vegetation classification using TWINSPAN identified five ecological species groups and the grouping was mainly dependent on topographic factor (e.g., elevation and slope) and soil properties (chemical and physical). In this study, ecological groups were used to assess the regeneration of some representative valuable tree and shrub species. Despite the protected status of the area, we found a slow rate of regeneration for all the species. In dry landscapes, recruitment of woody species is often episodic and related to a conjunction of favourable events that occur only for short time periods. When examining the abundance of the regeneration in the different ecological species groups we found a species-specific response. That is, seedling density was equally distributed among the different groups for some species (Q. brantii, C. pontica), but not for others (A. scoparia, C. microcarpa). We showed that the abundance of regeneration was controlled by specific environmental factors and topographic factors (e.g., elevation and slope), soil properties (e.g., bulk density, sand content, $\mathrm{K}$ and $\mathrm{P}$ conents) were the major ones controlling the regeneration success. These results can help to assess the suitability of sites for the development of woody species and can thus assist in developing forest restoration strategies.

\section{Acknowledgements}

We thank Dr. Morteza POURREZA and Dr. Yahya KOOCH for their critical reading of our manuscript, and Dr. Masoumeh NOUROZI for technical support.

\section{References}

Adel M N, Pourbabaei H, Dey C D. 2014. Ecological species group-environmental factors relationships in unharvested beech forests in the north of Iran. Ecological Engineering, 69: 1-7.

Basiri R. 2011. Cover percentage study of Quercus libani Oliv. In relation to elements distribution in soils using geostatistic methods in Sardasht, West Azarbaijan, Iran. Middle-East Journal of Scientific Research, 8(1): 114-124.

Bradbury I K, Malcolm D C. 1977. The effect of phosphorus and potassium on transpiration, leaf diffusive resistance and water-use efficiency in Sitka spruce (Picea sitchensis) seedlings. Journal of Applied Ecology, 14(2): 631-641.

Bremner J M. 1996. Nitrogen total. In: Sparks D L. Methods of Soil Analysis: Part 3-Chemical Methods. SSSA Book Series 5. Madison: Soil Science Society of America, 1085-1122.

Darvishnia H, Dehghani K M, Forghani A H, et al. 2012. Study and introducing of flora of the protected area of Manesht and Qalarang in Ilam province. Journal of Taxonomy and Biosistematics, 4(11): 47-60.

Dickie I A, Montgomery R A, Reich P B, et al. 2007. Physiological and phenological responses of oak seedlings to oak forest soil in the absence of trees. Tree Physiology, 27(1): 133-140.

Ghazanfari H, Namiranian M, Sobhani H, et al. 2004. Traditional forest management and its application to encourage public participation for sustainable forest management in the northern Zagros mountains of Kurdistan province, Iran. Scandinavian Journal of Forest Research, 19(Suppl. 4): 65-71.

Gómez-Aparicio L, Gómez J M, Zamora R. 2005. Microhabitats shift rank in suitability for seedling establishment depending on habitat type and climate. Journal of Ecology, 93(6): 1194-1202.

Gómez-Aparicio L, Pérez-Ramos I M, Mendoza I, et al. 2008. Oak seedling survival and growth along resource gradients in Mediterranean forests: implications for regeneration in current and future environmental scenarios. Oikos, 117(11): $1683-1699$.

Hattori D, Kenzo T, Irino K O, et al. 2013. Effects of soil compaction on the growth and mortality of planted dipterocarp seedlings in a logged-over tropical rainforest in Sarawak, Malaysia. Forest Ecology and Management, 310: 770-776.

Heydari M, Faramarzi M, Pothier D. 2016. Post-fire recovery of herbaceous species composition and diversity, and soil quality 
indicators one year after wildfire in a semi-arid oak woodland. Ecological Engineering, 94: 688-697.

Hill M O. 1979. TWINSPAN-a FORTRAN Program for Arranging Multivariate Data in an Ordered Two-way Table by Classification of the Individuals and Attributes. New York: Cornell University Press, 95.

Hill M O, Gauch H G Jr. 1980. Detrended correspondence analysis: an improved ordination technique. Vegetatio, 42(1-3): $47-58$.

Host G E, Pregitzer K S. 1991. Ecological species groups for upland forest ecosystems of northwestern lower Michigan. Forest Ecology and Management, 43(1-2): 87-102.

Ibáñez B, Ibáñez I, Gómez-Aparicio L, et al. 2014. Contrasting effects of climate change along life stages of a dominant tree species: the importance of soil-climate interactions. Diversity and Distributions, 20(8): 872-883.

Jazirehi M H, Ebrahimi R M. 2003. Silviculture in Zagros. Tehran: University of Tehran Press.

Kabrick J M, Dey D C, Van Sambeek J W, et al. 2005. Soil properties and growth of swamp white oak and pin oak on bedded soils in the lower Missouri River floodplain. Forest Ecology and Management, 204(2-3): 315-327.

Kalra Y P, Maynard D G. 1991. Methods manual for forest soil and plant analysis. In: Information Report NOR-X-319. Edmonton, AB: Forestry Canada.

Ko DW, Sparrow A D, Weisberg P J. 2011. Land-use legacy of historical tree harvesting for charcoal production in a semi-arid woodland. Forest Ecology and Management, 261(7): 1283-1292.

Mahoney J M, Rood S B. 1998. Streamflow requirements for cottonwood seedling recruitment-an integrative model. Wetlands, 18(4): 634-645.

Martín-Alcón S, Coll L. 2016. Unraveling the relative importance of factors driving post-fire regeneration trajectories in non-serotinous Pinus nigra forests. Forest Ecology and Management, 361: 13-22.

Marvie-Mohadjer M R. 2005. Silviculture. Tehran: University of Tehran Press, 387.

McLean E O. 1982. Soil pH and lime requirement. In: Page A L, Miller R H, Keeney R D. Methods of Soil Analysis, Part 2. Chemical and Microbiological Properties. Madison, WI: American Society of Agronomy, SSSA, 199-224.

Mirzaei J, Akbarinia M, Hosseini S M, et al. 2007. Comparison of natural regenerated woody species in relation to physiographic and soil factors in Zagros forests (Case study: Arghavan reservoir in north of Ilam province. Pajouhesh \& Sazandegi, (77): 16-23.

Mirzaei J. 2016. Impacts of two spatially and temporally isolated anthropogenic fire events on soils of oak-dominated Zagros forests of Iran. Turkish Journal of Agriculture and Forestry, 40(1): 109-119.

Mozaffarian V. 2008. Flora of Ilam. Tehran: Farhang Moaser Press, 936.

Müller-Dombois D, Ellenberg H. 1974. Aims and Methods of Vegetation Ecology. New York, NY: John Wiley and Sons, 547.

Park A D. 2001. Environmental influences on post-harvest natural regeneration in Mexican pine-oak forests. Forest Ecology and Management, 144(1-3): 213-228.

Pascual S, Olarieta J R, Rodríguez-Ochoa R. 2012. Development of Quercus ilex plantations is related to soil phosphorus availability on shallow calcareous soils. New Forests, 43(5-6): 805-814.

Peterson C J, Pickett S T A. 1990. Microsite and elevational influences on early forest regeneration after catastrophic windthrow. Journal of Vegetation Science, 1(5): 657-662.

Pourhashemi M, Mohajer M R M, Zobeiri M, et al. 2004. Identification of forest vegetation units in support of government management objectives in Zagros forests, Iran. Scandinavian Journal of Forest Research, 19(Suppl. 4): 72-77.

Rab M A. 1996. Soil physical and hydrological properties following logging and slash burning in the Eucalyptus regnans forest of southeastern Australia. Forest Ecology and Management, 84(1-3): 159-176.

Sagheb-Talebi K, Sajedi T, Yazdian F. 2004. Forests of Iran. Tehran: Research Institute of Forests and Rangelands Press, 56.

Salehi A, Karltun L C, Söderberg U, et al. 2010. Livelihood dependency on woodland resources in southern Zagros, Iran. Caspian Journal of Environmental Sciences, 8(2): 181-194.

Sardans J, Peñuelas J, Rodà F. 2005. Changes in nutrient use efficiency, status and retranslocation in young post-fire regeneration Pinus halepensis in response to sudden $\mathrm{N}$ and $\mathrm{P}$ input, irrigation and removal of competing vegetation. Trees, 19(3): 233-250.

Sardans J, Rodà F, Peñuelas J. 2006. Effects of a nutrient pulse supply on nutrient status of the Mediterranean trees Quercus ilex subsp. ballota and Pinus halepensis on different soils and under different competitive pressure. Trees, 20(5): 619-632.

Swetnam T W, Allen C D, Betancourt J L. 1999. Applied historical ecology: using the past to manage for the future. Ecological Applications, 9(4): 1189-1206.

Taylor J P, Wester D B, Smith L M. 1999. Soil disturbance, flood management, and riparian woody plant establishment in the Rio Grande floodplain. Wetlands, 19(2): 372-382. 
Tsitsoni T. 1997. Conditions determining natural regeneration after wildfires in the Pinus halepensis (Miller, 1768) forests of Kassandra Peninsula (North Greece). Forest Ecology and Management, 92(1-3): 199-208.

van Mantgem P J, Stephenson N L, Keeley J E. 2006. Forest reproduction along a climatic gradient in the Sierra Nevada, California. Forest Ecology and Management, 225(1-3): 391-399.

Walkley A, Black I A. 1934. An examination of the Degtjareff method for determining soil organic matter, and a proposed modification of the chromic acid titration method. Soil Science, 37(1): 29-38.

Watanabe F S, Olsen S R. 1965. Test of an ascorbic acid method for determining phosphorus in water and $\mathrm{NaHCO}_{3}$ extracts from soil. Soil Science Society of America Journal, 29(6): 677-678.

Zhao Z, Li P, Xue W P, et al. 2006. Relation between growth and vertical distribution of fine roots and soil density in the Weibei Loess Plateau. Frontiers of Forestry in China, 1(1): 76-81. 